\title{
MENJADIKAN MURID-NYA DI TENGAH MASYARAKAT MAJEMUK
}

\section{Dr. Daniel Stefanus}

\begin{abstract}
Abstrak:
Artikel ini merupakan ulasan salah satu peranan orang Kristen dalam masyarakat majemuk Indonesia. Salah satu peranan orang Kristen dalam masyarakat majemuk Indonesia adalah menjadi murid Kristus yang menjadikan orang lain menjadi murid Kristus yang toleran, pembawa damai, menjunjung tinggi perbedaan sebagai anugerah Tuhan yang terindah, serta memperlakukan orang lain yang berbeda agama, suku dan bahasanya sebagai sesama.
\end{abstract}

\section{A. Yesus sebagai Seorang Guru}

Biasanya kita menggambarkan Yesus dengan sebutan yang muluk dan abstrak, yaitu sebagai Tuhan, Juruselamat, Mesias, Putra Allah, Kepala Gereja atau lainnya. Itu tidak keliru. Tetapi keempat Kitab Injil menggambarkan Yesus dengan lebih konkret: Yesus adalah seorang guru.

Pekerjaan Yesus sebagai guru terutama digambarkan oleh Markus. Kitab Injil Markus secara dramatis memberi kesan seolah-olah Tuhan Yesus terus-menerus mengajar. Yesus

\footnotetext{
${ }^{1}$ Tema jurnal perdana Institut Wesley Jakarta adalah "Peranan Orang Kristen dalam Masyarakat Majemuk Indonesia". Penulis berpendapat salah satu peranan orang Kristen dalam masyarakat majemuk adalah menjadi murid Kristus yang menjadikan orang lain menjadi murid Kristus yang toleran, pembawa damai, menjunjung tinggi perbedaan sebagai anugerah Tuhan yang terindah, serta memperlakukan orang lain yang berbeda agama, suku dan bahasanya sebagai sesama.
} 
mengajar di sinagoge, di tepi danau, di jalan, di bukit, di pantai, di pinggir sumur, di manamana. Markus 6:6 mencatat, "Yesus berjalan keliling dari desa ke desa sambil mengajar."

Yesus adalah seorang guru. ${ }^{2}$ Bahkan Pheme Perkins menegaskan bahwa Yesus adalah seorang guru yang karismatik. ${ }^{3}$ Paling sedikit tampaknya ada enam bukti yang menunjukkan bahwa Yesus adalah seorang guru. Adapun keenam bukti tersebut adalah sebagai berikut:

1. Sebutan yang paling banyak digunakan untuk Yesus dalam keempat Injil adalah didaskalos, rabi dan rabuni. Sebutan didaskalos digunakan 42 kali dalam keempat Kitab Injil. Sebutan rabi 12 kali dan rabuni 2 kali. ${ }^{4}$ Didaskalos adalah kata Yunani yang berarti guru. Rabi dan Rabuni adalah kata Ibrani dan Aram yang juga berarti guru. Sapaan "rabi" bukan hanya sapaan pertama yang didengar Yesus pada awal pelayanan-Nya, melainkan juga sapaan pertama yang didengar-Nya setelah kebangkitan-Nya.

2. Yesus sendiri menyebut diri-Nya guru (lih. Mat. 23:8; Mrk. 14:14; Luk. 22:11; Yoh. 13:13-14).

3. Terlihat jelas di mana kegiatan Yesus lebih sering digambarkan dengan kata kerja "mengajar" daripada dengan kata kerja "memberitakan" atau "berkhotbah". Kata kerja didasko (mengajar) dalam berbagai bentuknya telah dipakai 9 kali dalam Matius, 15 kali dalam Markus dan Lukas, dan 8 kali dalam Yohanes. Mengajar adalah pekerjaan Tuhan Yesus yang utama. Memang Ia kerap kali berkhotbah, menyembuhkan orang sakit dan melakukan mukjizat, namun kegiatan-Nya yang paling utama adalah mengajar. Apa yang disebut khotbah Tuhan Yesus sebenarnya bukanlah khotbah, melainkan pengajaran di mana pendengar boleh menginterupsi dengan pertanyaan atau sanggahan. Yesus sendiri sering menginterupsi pengajaran-Nya untuk bertanya dan menguji para pendengar.

${ }^{2}$ Gunther Bornkamm, Jesus of Nazareth (London: Hodder \& Stoughton, 1960), 57.

${ }^{3}$ Pheme Perkins, Jesus as Teacher (New York: Cambridge University Press, 1990), 24.

${ }^{4}$ Andar Ismail, Selamat Menabur: 33 Renungan tentang Didik-Mendidik (Jakarta: BPK Gunung Mulia, 1997), 47. 
4. Yesus sangat mementingkan pekerjaan mengajar. Misalnya, dalam Markus 9 dicatat bahwa Yesus tidak mau ditemui atau diganggu orang karena Ia sedang mengajar.

5. Yesus tidak hanya disebut rabi oleh para murid-Nya tetapi juga disebut rabi oleh para musuh-Nya (lih. Mrk. 12:13-14). Yesus disapa sebagai seorang rabi oleh karena tampaknya Ia pernah dididik dalam sekolah yang mempersiapkan bakal rabi.

6. Di rumah ibadat Nazaret Ia dihormati sebagai seorang rabi pengunjung (lih. Luk. 4:16-21).

\section{B. Isi Ajaran Yesus}

Isi ajaran Yesus adalah tentang Kerajaan Allah, diri-Nya sendiri, kematian-Nya dan masa yang akan datang. ${ }^{5}$ Sementara itu, T.W. Manson menyatakan bahwa isi ajaran Yesus adalah Allah sebagai Bapa dan Allah sebagai Raja. ${ }^{6}$ Namun, tema utama pengajaran-Nya adalah Kerajaan Allah. Dalam Injil Markus istilah Kerajaan Allah terdapat 14 kali, sedangkan dalam Injil Lukas 32 kali. Dalam Injil Matius istilah Kerajaan Allah terdapat 4 kali dan Kerajaan Sorga terdapat 33 kali.

Kerajaan Sorga atau Kerajaan Allah sama artinya. Kerajaan Sorga diutamakan penginjil Matius oleh karena orang-orang Yahudi yang setia agak segan mengucapkan nama Allah. Matius berusaha menjauhkan diri dari penggunaan istilah yang dapat menyinggung perasaan orang-orang Yahudi untuk siapa Injilnya itu dimaksudkan. Ketiga penginjil lainnya, khususnya Markus dan Lukas memakai istilah "Kerajaan Allah" karena Injil mereka ditujukan kepada orang-orang bukan Yahudi. Kata Aram yang dipakai oleh Yesus untuk Kerajaan Allah adalah malkuth. Artinya pemerintahan (aktivitas) seorang raja. Jadi, dapat dikatakan bahwa Yesus berbicara tentang pemerintahan (aktivitas) Allah sebagai Raja dan

${ }^{5}$ A.M. Hunter, The Work and Words of Jesus (London: SCM Press, 1950), 68-111.

${ }^{6}$ T.W. Manson, The Teaching of Jesus (London: Cambridge University Press, 1963), 89-141. 
bukan wilayah kekuasaan-Nya. ${ }^{7}$ Andar Ismail menyatakan bahwa istilah malkuth bukan menggambarkan tempat atau wilayah dalam arti yang statis, melainkan menggambarkan kewibawaan atau tindakan dalam arti yang dinamis. ${ }^{8}$

Menurut pengajaran Yesus terdapat enam sifat Kerajaan Allah. Pertama, Kerajaan Allah sudah ada. Berbagai perumpamaan menunjukkan bahwa menurut Yesus Kerajaan Allah bukanlah sebuah suasana hati dan bukan pula pengharapan untuk hari depan, melainkan sebuah tindakan Allah untuk memulai suatu babak baru dalam sejarah, yang sudah dimulai dan sudah terjadi sejak sekarang ini. Sewaktu Yesus mengajar, Ia menegur para pendengar-Nya agar jangan jauh-jauh mencari Kerajaan itu karena Kerajaan sudah ada di antara mereka (lih. Luk. 17:21), yaitu dalam diri Yesus sendiri. Kerajaan Allah hadir dalam diri Yesus dalam tindakan-tindakan Yesus, misalnya: orang buta melihat, orang lumpuh berjalan, orang kusta menjadi tahir, orang tuli mendengar, orang mati dibangkitkan, setan diusir dan kepada orang miskin diberitakan kabar baik (lih. Mat. 11:5; Luk. 11:20). Kedua, Kerajaan Allah harus disambut secara pribadi. Jadi, Kerajaan Allah itu mempunyai dimensi kekinian yang berlaku pada setiap saat bagi orang-orang yang hidup (lih. Mrk. 10:15). Ketiga, Kerajaan Allah bersifat bertumbuh. Kerajaan Allah digambarkan sebagai sesuatu yang kecil tetapi secara diam-diam sedang bertumbuh. Contohnya adalah perumpamaan tentang penabur di Markus 4:3-8, tentang benih di Markus 4:26-29, tentang biji sesawi di Markus 4:30-32 dan tentang ragi di Lukas 13:20-21. Dalam semua contoh itu Kerajaan Allah digambarkan sebagai sesuatu yang kecil tetapi secara diam-diam sedang bertumbuh. Itulah Kerajaan Allah. Ia datang melalui pekerjaan Yesus yang kecil-kecilan, namun tanpa gembargembor ia sedang bertumbuh. Keempat, kehidupan dalam Kerajaan seperti yang diajarkan Yesus bukanlah kesempatan untuk bermalas-malasan sambil menikmatinya. Apabila orang-

\footnotetext{
7John Drane, Introducing the New Testament (England: Lion Publishing, 1950), 113.

${ }^{8}$ Andar Ismail, Selamat Berkiprah: 33 Renungan tentang Kesaksian (Jakarta: BPK Gunung Mulia, 2001), 60.
} 
orang tidak bertindak sebagai warga-warga yang bertanggung jawab maka "kewarganegaraan" mereka dapat dicabut dan diberikan kepada orang lain (lih. Mat. 21:43). Kelima, Kerajaan Allah bersifat masa yang akan datang. Kerajaan Allah dalam segala kelimpahannya adalah sesuatu yang masih harus kita nantikan kedatangannya pada suatu saat di masa yang akan datang. Yesus menyuruh para murid berdoa, "Bapa kami yang di sorga ... datanglah Kerajaan-Mu ... (lih. Mat. 6:9-10). Keenam, Allah yang membuat dan mendatangkan Kerajaan Allah bukan kita.

\section{Gaya Mengajar Yesus}

Yesus sebagai seorang guru memiliki berbagai gaya mengajar yang mampu menarik perhatian khalayak ramai (lih. Mrk. 1:22; 12:37). Adapun gaya mengajar Yesus sebagai berikut:

\section{Ceramah}

Dengan metode ceramah Yesus berusaha menyampaikan pengetahuan kepada muridmurid-Nya atau menafsirkan pengetahuan tersebut. Boehlke menegaskan bahwa melalui ceramah Yesus mengharapkan dua respons dari para pendengar-Nya, yakni: pengertian mendalam dan perilaku baru. ${ }^{9}$

\section{Bimbingan}

Yesus mengajar juga melalui bimbingan. Dalam Matius 10 misalnya, keduabelas murid telah menerima petunjuk-petunjuk dari Yesus untuk mengusir roh-roh jahat, melenyapkan segala penyakit dan memberitakan bahwa Kerajaan Sorga sudah dekat.

\section{Menghafalkan}

${ }^{9}$ Robert R. Boehlke, Sejarah Perkembangan Pikiran dan Praktek Pendidikan Agama Kristen dari Plato sampai IG. Loyola (Jakarta: BPK Gunung Mulia, 2009), 66. 
Setelah Yesus mengajarkan sesuatu atau selama Ia mengajarkan sesuatu, Yesus sering mengikhtisarkan isinya dalam suatu ucapan yang gampang dihafal, misalnya, “... Anak Manusia adalah Tuhan atas hari Sabat" (Mat. 12:8), "Bukan orang sehat yang memerlukan tabib, tetapi orang sakit” (Mat. 9:12), “... Anak Manusia juga datang bukan untuk dilayani, melainkan untuk melayani dan untuk memberikan nyawa-Nya menjadi tebusan bagi banyak orang" (Mrk. 10:45).

\section{Pewujudan}

Gaya mengajar "pewujudan” merupakan pendekatan khas Matius terhadap pelayanan Yesus. Tuhan Yesus dilukiskan sebagai seorang yang telah mewujudkan dalam diri pribadiNya sebagian dari sejarah bangsa Israel. Ia, sama halnya seperti keturunan Yakub, turun ke Mesir agar diloloskan dari bahaya. Kemudian, Yesus pun adalah yang dipanggil keluar dari Mesir (lih. Mat. 2:13-15). Lalu ada masa pencobaan di padang gurun yang sejajar dengan pengalaman bangsa Israel di Sinai (lih. Mat. 4:1-11). Pewujudan lebih mendalam artinya daripada hanya teknik memainkan peran, sebab teknik memainkan peran hanya berlaku untuk waktu yang sementara saja, sedangkan dengan pewujudan Yesus mengajarkan kepada muridmurid-Nya bahwa diri pribadi-Nyalah penyataan yang baru itu.

\section{Dialog}

Gaya mengajar dialog yang dilakukan Yesus banyak sekali contohnya dalam keempat Injil (misalnya: Mat. 19:16-26; Yoh. 4). Yesus sering mengajukan pertanyaan yang baru sebagai tanggapan-Nya atas pertanyaan yang sebelumnya yang diajukan kepada-Nya.

\section{Studi Kasus}


Perumpamaan yang diceritakan Yesus merupakan studi kasus. Oleh karena itu, gaya mengajar studi kasus disebut juga gaya mengajar yang memakai perumpamaan. ${ }^{10}$ Dengan studi kasus, misalnya “Anak yang Hilang”, para pendengar-Nya didorong untuk memikirkan inti persoalan dan bagaimana memecahkannya.

\section{Perjumpaan}

Gaya mengajar perjumpaan disebut juga gaya mengajar yang memakai pertanyaan. ${ }^{11}$ Dengan gaya mengajar perjumpaan, para pelajar ditantang secara langsung untuk mengambil keputusan. Di sini Yesus tidak bercerita. Ia memprakarsai pertanyaan yang pribadi dan besar sekali maknanya, misalnya, “Tetapi apa katamu, siapakah Aku ini?” (Mat. 16:15), “Diperbolehkankah menyembuhkan orang pada hari Sabat atau tidak?” (Luk. 14:3), “Percayakah engkau kepada Anak Manusia?” (Yoh. 9:35).

\section{Perbuatan Simbolis}

Dengan Yesus dibaptiskan oleh Yohanes Pembaptis pada awal pelayanan Yesus, Yesus ingin mengajar murid-murid-Nya melalui perbuatan simbolis ini. Pertama-tama Ia mengajarkan bahwa pelayanan-Nya berarti perlunya pengorbanan diri sebagai tujuan utama kehidupan-Nya. Hubungan antara pengorbanan dan baptisan dinyatakan melalui jawabanNya kepada Yakobus dan Yohanes yang memohon agar mereka boleh menerima hak istimewa nanti. Kata Yesus, "Dapatkah kamu dibaptis dengan baptisan yang harus Kuterima?" (Mrk. 10:38). Dalam hal ini baptisan-Nya merupakan lambang kesengsaraan-Nya nanti. Kedua, melalui lambang baptisan itu Yesus mengajarkan perlunya solider dengan semua orang. Contoh-contoh gaya mengajar perbuatan simbolis yang lain dapat kita temui dalam peristiwa pertemuan Yesus dengan Zakheus (lih. Luk. 19:5) dan pembasuhan kaki para

\footnotetext{
${ }^{10} \mathrm{lbid}, 68$.

${ }^{11}$ Ibid., 69.
} 
murid (lih. Yoh. 13:12-15). Selain itu, pemilihan duabelas murid adalah perbuatan simbolis. Mengapa Yesus memanggil justru duabelas orang dan bukan sepuluh atau empatbelas? Keduabelas orang itu melambangkan keduabelas anak-anak Yakub, dan artinya ialah bahwa Yesus sedang mendirikan Israel yang baru (lih. Mrk. 3:14-19).

9. Ucapan yang Berlebih-lebihan

Ucapan yang berlebih-lebihan digunakan untuk menonjolkan pesan secara mencolok. ${ }^{12}$ Selain itu, untuk mempertajam kebenaran tertentu di mana Yesus menitikberatkan sesuatu dengan jalan mengatakan sesuatu yang sebenarnya tidak boleh diterima secara harfiah. Ketika Yesus berkata, "Jikalau seorang datang kepada-Ku dan ia tidak membenci bapanya, ibunya, istrinya, anak-anaknya, saudara-saudaranya laki-laki atau perempuan, bahkan nyawanya sendiri, ia tidak dapat menjadi murid-Ku" (Luk. 14:26), Ia menitikberatkan fakta bahwa mengikut Dia bukan sesuatu yang dapat dilakukan secara sambil lalu. Hubungan apapun tidak boleh dianggap lebih penting daripada mengabdikan diri mereka kepada Allah. Ketika Yesus menasihatkan tentang perlunya memenggal tangan atau kaki ataupun mencungkil mata apabila masing-masing tangan, kaki atau mata itu menyesatkan seseorang (lih. Mrk. 9:43-47), Ia bermaksud agar orang-orang memisahkan dirinya dari apa saja yang merupakan penghalang untuk mengikut Dia.

10. Ucapan yang Berisi Permainan Kata

Yesus ahli sekali bermain dengan kata-kata, tetapi pendekatan semacam itu hanya dapat kita ketahui kalau kita mengerti bahasa Yesus, yaitu bahasa Aram. Ketika Ia mengecam kaum Farisi karena mereka sangat teliti dalam usaha menaati peraturan secara harfiah, sementara tidak menaruh perhatian terhadap keadilan, belas kasihan dan kesetiaan, maka Ia

\footnotetext{
${ }^{12}$ Andar Ismail, Selamat Mengikut Dia!: 33 Renungan tentang Kristus (Jakarta: BPK Gunung Mulia, 1994), 11.
} 
berkata, "Hai kamu pemimpin-pemimpin buta, nyamuk kamu tapiskan dari dalam minumanmu, tetapi unta yang di dalamnya kamu telan” (Mat. 23:24). Dalam bahasa Aram, baik "nyamuk" maupun "unta", bunyi katanya hampir serupa, yaitu galma dan gamla sehingga Yesus mengatakan, "Hai kamu pemimpin-pemimpin buta, galma kamu tapiskan dari dalam minumanmu, tetapi gamla di dalamnya kamu telan."

Permainan kata lainnya kita temukan dalam ucapan terkenal Yesus yang dialamatkan kepada Petrus, "Engkau adalah Petrus dan di atas batu karang ini Aku akan mendirikan jemaat-Ku dan alam maut tidak akan menguasainya" (Mat. 16:18). Dalam bahasa Aram, baik batu maupun nama pribadi seseorang dinyatakan dengan kata yang sama, yaitu kefa. Oleh karena itu, Yesus mengatakan, "Engkau adalah Kefa dan di atas kefa ini Aku akan mendirikan jemaat-Ku." Dengan permainan kata seperti itu Yesus berhasil menyampaikan amanat-Nya dengan cara yang segar dan menarik.

\section{Gaya Mengajar yang Memakai Tamsil}

Kadang-kadang Yesus mengajar dengan jalan memakai suatu tamsil, misalnya, "Maka seperti lalang itu dikumpulkan dan dibakar dalam api, demikian juga pada akhir zaman" (Mat. 13:40) atau "Pada waktu itulah orang-orang benar akan bercahaya seperti matahari dalam Kerajaan Bapa mereka" (Mat. 13:43). Juga ayat yang sering dikutip oleh para pendidik digolongkan dalam tamsil, yaitu, "Sesungguhnya barangsiapa yang tidak menyambut Kerajaan Allah seperti seorang anak kecil, ia tidak akan masuk ke dalamnya" (Mrk. 10:15). Dalam tamsil biasanya persamaan itu diperkenalkan melalui penggunaan kata: seperti, sebagai dan sebagaimana.

12. Gaya Mengajar yang Memakai Kiasan atau Metafora 
Dalam kiasan atau metafora persamaan antara dua gagasan atau keadaan ditunjukkan secara langsung tanpa memakai sesuatu kata perkenalan. ${ }^{13}$ Misalnya, menurut Matius 5:13 orang-orang yang percaya kepada Yesus tidak disamakan dengan garam, melainkan mereka adalah garam. Selain itu, dalam kecaman-Nya yang pedas terhadap kaum Farisi, mereka disebut ular dan bukan seperti ular.

13. Gaya Mengajar yang Memakai Bentuk Argumentasi "Jika ..., Apalagi ..."

Setelah Yesus menyatakan bahwa kesulitan bahkan penganiayaan akan merupakan bagian mereka Yesus berkata, "Cukuplah bagi seorang murid jika ia menjadi sama seperti gurunya dan bagi seorang hamba jika ia menjadi sama seperti tuannya. Jika tuan rumah disebut Beelzebul, apalagi seisi rumahnya” (Mat. 10:25). Dalam pengajaran-Nya tentang berdoa, Yesus akhirnya menarik kesimpulan berdasarkan formula yang sama, yaitu: "Jadi jika kamu yang jahat tahu memberi pemberian yang baik kepada anak-anakmu, apalagi Bapamu yang di sorga!" (Luk. 11:13a).

Tetapi kadang-kadang “jika” dan "apalagi” itu tersirat dalam kesimpulan. Misalnya, kepada para penentang-Nya yang tidak konsekuen yang mengecam Yesus menyembuhkan seorang perempuan pada hari Sabat, Yesus menegaskan: "Hai orang-orang munafik, bukankah setiap orang di antaramu melepaskan lembunya atau keledainya pada hari Sabat dari kandangnya dan membawanya ke tempat minuman? Bukankah perempuan ini, yang sudah delapanbelas tahun diikat oleh Iblis, harus dilepaskan dari ikatannya itu, karena ia adalah keturunan Abraham?" (Luk. 13:15-16).

14. Persejajaran yang Sinonimus

\footnotetext{
${ }^{13}$ Robert H. Stein, The Method and Message of Jesus' Teachings (Philadelphia: The Westminster Press, 1978), 16 .
} 
Persejajaran yang sinonimus adalah gaya mengajar di mana baris atau kalimat pertama diucapkan ulang dengan kata yang sama dalam baris kedua. Contoh-contoh persejajaran yang sinonimus terdapat dalam Markus 3:24-25 yang berbunyi "Kalau suatu kerajaan terpecah-pecah, kerajaan itu tidak dapat bertahan, dan jika suatu rumah tangga terpecah-pecah, rumah tangga itu tidak dapat bertahan"; Markus 4:22 yang berbunyi, "Sebab tidak ada sesuatu yang tersembunyi yang tidak akan dinyatakan, dan tidak ada sesuatu yang rahasia yang tidak akan tersingkap" dan Matius 7:7-8 yang berbunyi, "Mintalah, maka akan diberikan kepadamu; carilah, maka kamu akan mendapat; ketoklah, maka pintu akan dibukakan bagimu. Karena setiap orang yang meminta, menerima dan setiap orang yang mencari akan mendapat, dan setiap orang yang mengetok, baginya pintu dibukakan.”

Dalam kutipan dari Markus 3 dan 4 di atas, kita dapat melihat bagaimana baris kedua itu menitikberatkan gagasan yang sama yang disampaikan melalui baris pertama, tetapi dengan kata-kata yang berlainan. Melalui teknik itu artinya menjadi semakin jelas. Kutipan dari Matius 7, bentuknya berbeda, bukan satu baris yang mengulangi lagi gagasan pokok dalam baris pertama, melainkan dua baris yang fungsinya sama, yaitu kata kerja "carilah" dan "ketoklah" yang artinya tidak begitu berbeda dari inti kata yang pertama, yakni "mintalah". Baris yang paling akhir merupakan rangkuman dari keseluruhannya.

\section{Persejajaran yang Antitetis}

Dalam persejajaran yang antitetis baris yang kedua bertentangan dengan yang pertama sehingga gagasan pokoknya semakin nyata. Contoh-contoh persejajaran yang antitetis terdapat dalam Markus 8:35 yang berbunyi, "Karena siapa yang mau menyelamatkan nyawanya, ia akan kehilangan nyawanya; tetapi barangsiapa kehilangan nyawanya karena Aku dan karena Injil, ia akan menyelamatkannya"; Lukas 6:21a yang berbunyi, "Berbahagialah, hai kamu yang sekarang ini lapar karena kamu akan dipuaskan"; Lukas 
6:25a yang berbunyi, "Celakalah kamu yang sekarang ini kenyang, karena kamu akan lapar"; dan Lukas 16:10 yang berbunyi, "Barangsiapa setia dalam perkara-perkara kecil, ia setia juga dalam perkara-perkara besar. Dan barangsiapa tidak benar dalam perkara-perkara kecil, ia tidak benar juga dalam perkara-perkara besar.”

\section{Persejajaran yang Sintetis}

Persejajaran yang sintetis tidak mengulangi dalam baris kedua yang sudah tampak dalam baris pertama, juga tidak mempertentangkan baris kedua dengan baris pertama. Sebagai gantinya, gagasan pokok dinyatakan dalam baris pertama, dan baris yang selanjutnya membangun di atasnya atau meneruskan gagasan yang sama sampai artinya semakin lengkap. Contoh persejajaran yang sintetis terdapat dalam Matius 23:5-7 yang berbunyi, "Mereka memakai tali sembahyang yang lebar dan jumbai yang panjang; Mereka suka duduk di tempat terhormat dalam perjamuan dan di tempat terdepan di rumah ibadat; Mereka suka menerima penghormatan di pasar, dan suka dipanggil Rabi.” Baris pertama menyampaikan gagasan pokok, yaitu: "Semua pekerjaan yang mereka lakukan hanya dimaksud supaya dilihat orang." Lantas kita diberitahukan dengan cara bagaimana mereka bertindak supaya dilihat orang.

\section{Persejajaran yang Klimaktis}

Dalam persejajaran yang sintetis dan persejajaran yang klimaktis, baris kedua tidak mengulangi arti baris pertama, melainkan dalam baris kedua gagasan pokok dari baris pertama diperluas atau dikembangkan lebih lanjut. Tetapi dalam persejajaran yang klimaktis, gagasan pokok itu mencapai puncaknya dalam baris kedua. Boleh dikatakan bahwa baris kedua itu meningkatkan arti yang disebut dalam baris pertama. Contoh-contoh persejajaran yang klimaktis terdapat dalam Markus 9:37 yang berbunyi, "Barangsiapa menyambut seorang anak seperti ini dalam nama-Ku, ia menyambut Aku. Dan barangsiapa menyambut 
Aku, bukan Aku yang disambutnya, tetapi Dia yang mengutus Aku"; dan Matius 5:17 yang berbunyi, "Janganlah kamu menyangka, bahwa Aku datang untuk meniadakan hukum Taurat atau kitab para nabi. Aku datang bukan untuk meniadakannya, melainkan untuk menggenapinya."

18. Gaya Mengajar yang Memakai Ucapan Peribahasa

Kadang-kadang Yesus mengajar dengan jalan memakai ucapan peribahasa, misalnya, "Ikutlah Aku dan biarlah orang-orang mati menguburkan orang-orang mati mereka" (Mat. 8:22) atau "Setiap orang yang siap membajak tetapi menoleh ke belakang, tidak layak untuk Kerajaan Allah" (Luk. 9:62). Ucapan Yesus yang terdapat dalam Matius 8:22 sebenarnya berasal dari peribahasa Ibrani yang berbunyi, "Seperti membiarkan orang mati menguburkan orang mati." Perbuatan itu berarti perbuatan yang sangat tidak bertanggung jawab sebab dalam masyarakat Yahudi mengurus pemakaman merupakan suatu tanggung jawab keluarga dan komunitas. Melakukan pemakaman secara baik dinilai sangat penting.

Tuhan Yesus sebagai anggota komunitas Yahudi tahu betul adat yang berlaku, yakni menguburkan orang meninggal adalah perkara yang sangat penting. Namun, Yesus berkata, "Ikutlah Aku, biarlah orang mati menguburkan orang mati." Maksud Yesus adalah menguburkan orang mati adalah sangat penting tetapi mengikut Yesus adalah lebih penting lagi. Dengan perkataan lain, mengikut Yesus adalah urusan yang lebih penting dari urusan yang paling penting, yakni: menguburkan jenazah ayahnya. ${ }^{14}$ Jadi, di sini Yesus sama sekali bukan bermaksud agar orang itu menelantarkan pemakaman ayahnya. Di sini Yesus menekankan tingginya nilai mengikut Dia.

\footnotetext{
${ }^{14}$ Andar Ismail, Selamat Mengikut Dia!: 33 Renungan tentang Kristus (Jakarta: BPK Gunung Mulia, 1994), 9.
} 
Ucapan Yesus yang terdapat dalam Lukas 9:62 pun termasuk ucapan peribahasa. Pada zaman itu ada peribahasa Ibrani yang berbunyi, "Seperti orang membajak dan menoleh ke belakang", artinya melakukan sesuatu tidak dengan sepenuh hati. Dengan menggunakan peribahasa itu, Yesus menanggapi orang yang berkata, "Aku akan mengikut Engkau, Tuhan, tetapi izinkanlah aku pamitan dahulu dengan keluargaku" (Luk. 9:61). Di sini Yesus bukan melarang orang itu berpamitan. Di sini Yesus ingin menegaskan mengikut Yesus bukan perbuatan yang bisa dilakukan dengan setengah-setengah. Dengan perkataan lain, Yesus menekankan kesungguhan hati dalam mengikut Dia.

\section{Menjadikan Orang Lain sebagai Murid-Nya}

Yesus sebagai seorang guru memiliki murid. Murid adalah orang yang menaklukkan keinginannya di bawah keinginan gurunya. ${ }^{15}$ Murid adalah orang yang memberi dirinya, baik pikiran dan perbuatannya, dipimpin oleh gurunya. Murid adalah orang yang melepaskan gaya hidupnya lalu mengikuti gaya hidup gurunya. Ini terjadi melalui proses penyatuan di mana murid dan guru saling menyatu: "Jikalau kamu tinggal dalam Aku dan firman-Ku tinggal dalam kamu,... kamu berbuah banyak dan dengan demikian kamu adalah murid-murid-Ku" (Yoh. 15:7-8).

Murid-murid Yesus ialah pertama-tama mereka, yang Ia sendiri pilih dan panggil untuk mengikuti-Nya dalam pelayanan-Nya. Mereka biasa disebut rasul-rasul. Tetapi bukan mereka saja adalah murid-murid Yesus. Dari Kisah Para Rasul 11:26 nyata, bahwa semua orang yang oleh pekerjaan Roh Kudus percaya kepada-Nya adalah murid-murid-Nya. Semua orang yang melalui karya Roh Kudus menerima Firman Tuhan sebagai kebenaran dapat disebut murid Yesus Kristus. ${ }^{16}$ Naradidik Yesus adalah orang dewasa. ${ }^{17}$ Hanya ada satu dua

${ }^{15}$ J.L. Ch. Abineno, Sekitar Katekese Gerejawi (Jakarta: BPK Gunung Mulia, 1988), 18.

${ }^{16}$ G. Riemer, Ajarlah Mereka: Pedoman Ilmu Katekese (Jakarta: Yayasan Komunikasi Bina Kasih, 1998), 28. 
kejadian di mana kitab-kitab Injil mencatat bahwa anak-anak kecil disapa Yesus secara langsung sebagai naradidik Yesus.

Apa syarat masuk kalau mau menjadi murid Tuhan Yesus? Yesus berkata, "Jikalau seorang datang kepada-Ku dan ia tidak membenci bapanya, ibunya, istrinya, anak-anaknya, saudaranya laki-laki atau perempuan, bahkan nyawanya sendiri, ia tidak dapat menjadi murid-Ku” (Luk. 14:26).

Ucapan yang membingungkan itu langsung diberi penjelasan dengan dua buah gambaran. Pertama: "Sebab siapakah di antara kamu yang kalau mau mendirikan sebuah menara tidak duduk dahulu membuat anggaran biayanya ...?” (ay. 28). Kedua: “Atau, raja manakah yang kalau mau pergi berperang melawan raja lain tidak duduk dahulu untuk mempertimbangkan, apakah dengan sepuluh ribu orang ia sanggup menghadapi lawan ...?" (ay. 31). Segera setelah memberi dua gambaran itu Yesus membuat semacam kesimpulan: "Demikian pulalah tiap-tiap orang di antara kamu, yang tidak melepaskan dirinya dari segala miliknya, tidak dapat menjadi murid-Ku" (ay. 33).

Kedua gambaran berikut kesimpulannya mulai menguak maksud ucapan Yesus, yaitu bahwa ada risiko atau konsekuensi jika menjadi murid-Nya. Menjadi murid Yesus berarti mengikatkan diri kepada Yesus. Keterikatan yang baru ini hanya mungkin terjadi jika kita melepaskan segala keterikatan lama yang bisa jadi bertolak belakang dengan Yesus. Untuk menggambarkan keterikatan lama itu Yesus menyebut keterikatan dengan keluarga, sebab dalam budaya Yahudi ikatan keluarga sangat kuat, misalnya adik laki-laki harus menikah dengan istri kakaknya jika kakaknya itu meninggal.

${ }^{17}$ Lih. Andar Ismail, "Sebuah Teologi Pendidikan Kristen Orang Dewasa," dalam Mulai dari Musa dan Segala Nabi, peny. Andar Ismail (Jakarta: BPK Gunung Mulia, 1996), 110. 
Jadi ucapan Yesus tentang "Membenci bapaknya, ibunya, istrinya ..." bukan dimaksudkan harfiah. Maksud Yesus adalah bahwa bila kita mau menjadi murid Yesus maka komitmen kita kepada Yesus perlu diletakkan di atas segala komitmen kita yang lain. ${ }^{18}$ Bisa jadi ada komitmen kepada keluarga yang bertolak belakang dengan komitmen kepada Yesus. Misalnya, dalam budaya tertentu seorang anak wajib bersumpah di depan peti jenazah ayahnya untuk membalas dendam kepada musuh ayahnya. Padahal gaya hidup Yesus adalah mengampuni.

Menjadi murid Yesus berkonsekuensi melepaskan diri dari gaya hidup yang bertolak belakang dengan Yesus. Sebab itu Yesus berpahit-pahit kepada seorang kaya yang mau menjadi murid-Nya, "Juallah segala yang kau miliki dan bagi-bagikanlah itu kepada orangorang miskin ... dan ikutlah Aku" (Luk. 18:22). Menjadi murid Yesus berarti bersedia melepaskan diri dari keterikatan kepada gaya hidup yang mengutamakan harta benda.

Melepaskan diri dari gaya hidup atau budaya yang lama biasanya tidak mudah dan untuk itu dibutuhkan pengorbanan dan kesediaan menderita. Dalam konteks ini Yesus bersabda, "Barang siapa tidak memikul salibnya dan mengikut Aku, ia tidak dapat menjadi murid-Ku (Luk. 14:27). Ucapan-ucapan Yesus ini mengandung arti bahwa menjadi muridNya tidak boleh disertai motivasi untuk memperoleh keuntungan atau sukses ini dan itu, melainkan justru sebaliknya, yaitu bersedia menanggung konsekuensi-konsekuensi yang timbul di sepanjang perjalanan.

Yesus juga berkata, "Setiap orang yang mau mengikut Aku, ia harus menyangkal dirinya, memikul salibnya setiap hari dan mengikut Aku” (Luk. 9:23). Menyangkal diri berarti mengalahkan kepentingan dan keinginan sendiri. Menjadi murid Yesus memang bukan berarti mendapat manfaat supaya keinginan-keinginan kita terkabul, melainkan

\footnotetext{
${ }^{18}$ Andar Ismail, Selamat Menabur: 33 Renungan tentang Didik-Mendidik (Jakarta: BPK Gunung Mulia, 1997), 41.
} 
sebaliknya yaitu belajar menempatkan keinginan kita di bawah keinginan Tuhan. Yesus pun berdoa, "Bukanlah kehendak-Ku, melainkan kehendak-Mulah yang terjadi” (Luk. 22:42).

Murid yang bagaimana yang dikehendaki oleh Yesus Kristus? Yesus berkata, “... jadikanlah semua bangsa murid-Ku dan baptislah mereka dalam nama Bapa dan Anak dan Roh Kudus, dan ajarlah mereka melakukan segala sesuatu yang telah Kuperintahkan kepadamu” (Mat. 28:19-20). Perhatikan ketiga intinya: "jadikanlah semua bangsa murid-Ku”, "baptislah mereka dalam nama Bapa dan Anak dan Roh Kudus" dan "ajarlah mereka melakukan segala sesuatu yang telah Kuperintahkan kepadamu". ${ }^{19}$

Inti pertama adalah tentang hakikat murid. "Menjadi murid" dan "menjadikan murid" merupakan konsep sentral dalam Injil Matius (Yun.: matheteuein, hanya dipakai empat kali di Perjanjian Baru, tiga di antaranya oleh Matius). Kata kerja yang biasanya dihubungkan oleh Matius dengan murid adalah mengikut dan melakukan. Menjadi murid adalah mengikut guru dan melakukan kehendaknya. Menjadi murid berarti hidup sesuai dengan ajaran guru dan membuahkannya dalam bentuk perilaku sehari-hari. Menjadi murid bukanlah hanya sebuah status, melainkan sebuah gaya hidup dengan sebuah misi "supaya mereka melihat perbuatanmu" (Mat. 5:16) dan dengan sebuah tujuan "supaya mereka ... memuliakan Bapamu" (Mat. 5:16). Di sini tampak kaitan antara menjadi murid dan menjadikan murid. Gaya hidup sebagai murid akan membuat orang lain menjadi murid Tuhan. Yesus tidak rasialis. Tidak diskriminatif. Dia ingin semua bangsa menjadi murid-Nya. Tidak cuma jadi Kristen. Tidak cuma bertukar agama. Tetapi menjadi murid Kristus.

Inti kedua adalah tentang identitas: "baptislah mereka dalam nama Bapa dan Anak dan Roh Kudus". Matius mengakui keyahudian mereka. Namun mereka sekarang sudah mengikuti gaya hidup Yesus. Sebab itu sekarang mereka berbeda. Baptisan mereka bukan

\footnotetext{
${ }^{19}$ Andar Ismail, Selamat Berkiprah: 33 Renungan tentang Kesaksian (Jakarta: BPK Gunung Mulia, 2001), 111.
} 
lagi baptisan Yahudi melainkan baptisan "dalam nama Bapa dan Anak dan Roh Kudus". Mereka bukan lagi sebuah bangsa yang terpisah, melainkan sebuah bagian dari "semua bangsa”.

Inti ketiga adalah tentang belajar dan mengajar: “ajarlah mereka melakukan segala sesuatu yang telah Kuperintahkan kepadamu". Untuk bisa mengajar orang perlu belajar terlebih dulu. Di dalam mengajar kita belajar. Belajar apa dan mengajar apa? Belajar dan mengajar untuk "melakukan segala sesuatu yang telah Kuperintahkan kepadamu". Kita belajar bukan sekadar untuk mengetahui, melainkan untuk melakukan. Belajar bukan hanya menyangkut ranah pikiran, melainkan juga ranah perasaan dan ranah kesediaan untuk melakukan.

Itulah inti Amanat Agung. Apakah amanat itu masih berlaku sekarang? Tentu saja. Kita dipanggil untuk berkiprah sebagai murid Yesus sedemikian rupa sehingga hidup kita itu menjadikan orang lain juga murid-Nya di tengah masyarakat majemuk. Oleh sebab itu, salah satu peranan orang Kristen dalam masyarakat majemuk adalah menjadi murid Kristus yang menjadikan orang lain menjadi murid Kristus yang toleran, pembawa damai, menjunjung tinggi perbedaan sebagai anugerah Tuhan yang terindah, serta memperlakukan orang lain yang berbeda agama, suku dan bahasanya sebagai sesama.

\section{DAFTAR PUSTAKA}

Abineno, J.L. Ch. Sekitar Katekese Gerejawi. Jakarta: BPK Gunung Mulia, 1988.

Boehlke, Robert R. Sejarah Perkembangan Pikiran dan Praktek Pendidikan Agama

Kristen dari Plato sampai IG. Loyola. Jakarta: BPK Gunung Mulia, 2009. 
Bornkamm, Gunther. Jesus of Nazareth. London: Hodder \& Stoughton, 1960.

Drane, John. Introducing the New Testament. England: Lion Publishing, 1950.

Hunter, A.M. The Work and Words of Jesus. London: SCM Press, 1950.

Ismail, Andar. Selamat Mengikut Dia!: 33 Renungan tentang Kristus. Jakarta: BPK

Gunung Mulia, 1994.

, "Sebuah Teologi Pendidikan Kristen Orang Dewasa.” Dalam Mulai dari

Musa dan Segala Nabi, peny. Andar Ismail. Jakarta: BPK Gunung Mulia, 1996.

, Selamat Menabur: 33 Renungan tentang Didik-Mendidik. Jakarta: BPK

Gunung Mulia, 1997.

, Selamat Berkiprah: 33 Renungan tentang Kesaksian. Jakarta: BPK

Gunung Mulia, 2001.

Manson, T.W. The Teaching of Jesus. London: Cambrigde University Press, 1963.

Perkins, Pheme. Jesus as Teacher. New York: Cambrigde University Press, 1990.

Riemer, G. Ajarlah Mereka: Pedoman Ilmu Katekese. Jakarta: Yayasan Komunikasi

Bina Kasih, 1998.

Stein, Robert H. The Method and Message of Jesus' Teachings. Philadelphia: The

Westminster Press, 1978. 
